\title{
Re-shaping the EHEA After the Demise of Neoliberalism: A UK-Informed Perspective
}

\author{
Linda Evans
}

\section{Introduction}

Reflecting neoliberalism's “fundamental principle: the superiority of individualized, market-based competition over other modes of organization" (Mudge 2008: 706-707), the UK's universities — along with those in many European countrieshave, over the last two decades or so, fitted themselves out with what are generally considered the trappings of neoliberalism: new public management, performativity, competitiveness, consumerism, and the commodification of services and personnel. The European Higher Education Area (EHEA) has inevitably emerged as a product of this incremental metamorphosis; reflecting the sum of its constituent partsindividual European nations' higher education sectors and systems-for the most part it is essentially a neoliberal higher education area. But now, subtle shifts are discernible and faint rumblings audible - which some commentators have interpreted as the overture to neoliberalism's death knell. Representing a recent perspectival shift from resignation that the dark neoliberal night is still young-with Kauppi (2015: 32), for example, lamenting that "[n]othing seems to stop the triumph of neoliberalism in academe", and Mason (2015, p. xii) similarly noting that "[o]ver the past two decades, millions of people have resisted neoliberalism but in general the resistance has failed"-are increasingly expressed predictions that the model has run its course and a new day is about to dawn. It is difficult to gauge how imminent is its demise, but when neoliberalism eventually does - as it inevitably will - become consigned to history, quite a different style of university must emerge from its shadow, and with it, the EHEA's shape and form will be redefined.

Predominantly conceptual and analytical, and based upon conjecture, deduction and hypothesis, this chapter addresses the questions: What might the post-neoliberal

\footnotetext{
L. Evans $(\bowtie)$

University of Manchester, Manchester, UK

e-mail: linda.evans@manchester.ac.uk

(C) The Author(s) 2018

A. Curaj et al. (eds.), European Higher Education Area: The Impact of Past and Future Policies, https://doi.org/10.1007/978-3-319-77407-7_3
} 
university look like? - and how might it impact upon academic life within the EHEA? As a prelude to such consideration, I first outline evidence that neoliberalism's grip on the European academy is indeed believed to be slackening.

\section{The Beginning of the End, or the End of the Beginning? the Popular Backlash to Neoliberalism}

As Zanoni et al. (2017: 575) note: "we are today witnessing epochal changes, which are fundamentally redefining the social, economic, political, and environmental realities we live in unforeseen and unimaginable ways". Symptomatic of what Jacques (2016) calls a "popular backlash" to the felt effects of "the most disastrous feature of the neoliberal period"_- "the huge growth in inequality"-electoral predictions and political "certainties" have been overturned, with, for example, Emmanuel Macron's victory in the French presidential election of 2017 having "shattered the accepted wisdom of French politics" (Bock 2017), and politically inexperienced Donald Trump's controversial snatching of the US presidency from under the nose of a seasoned politician who, until the eleventh hour, looked every inch the front-runner (yet, perhaps equally threatening to the status quo in the USA was the surge of support for left-wing Bernie Sanders's candidacy for the Democratic presidential nomination). It was moreover argued before the 2016 US presidential election took place that "Trump's position represents a major critique of America as the world's hegemon. His arguments mark a radical break with the neoliberal, hyper-globalisation ideology that has reigned since the early 1980s" (Jacques 2016).

Adding detail to this increasingly global scenario of unpredictability and cast-off of the familiarity of the status quo are recent political events in the UK, where the aftershock of the 2016 Brexit referendum earthquake remains palpable, and where the electorate sent further shockwaves resounding through Whitehall's corridors of power in the general election of 2017, when, on the basis of a manifesto that was unequivocally social justice-, anti-austerity- and public services democratisation-focused, the Labour Party dashed predictions of a Conservative landslide victory, wiping out the Tories' fragile majority and strengthening the power base of left-wing Labour leader Jeremy Corbyn. In diverting directions of travel envisaged by the political masters and mistresses who had plotted the original policy itineraries, such subtle (and sometimes not so subtle) shifts and twists and turns away from acquiescence with prevailing hegemonies essentially reflect an appetite for fairer and more palatable ways of running countries and organising society_for inequality, argues Jacques (2016):

is, bar none, the issue that is driving the political discontent that is now engulfing the west. Given the statistical evidence, it is puzzling, shocking even, that it has been disregarded for so long; the explanation can only lie in the sheer extent of the hegemony of neoliberalism and its values. 
Such evident distaste for what is currently being served up at the macro level of organised society seems very likely not only to spill over to, but also to have its origins in, dissatisfaction focused on the meso level and manifested as demands for changes in how organisations and institutions are run-and on what principles, and reflecting what ideologies. Indeed, Jacques (2016) traces popular outrage against banks and bankers-over the societal inequalities that they represented and the ethically questionable practices that had become embedded within their occupational culture - as the prequel to demonstrations of dissatisfaction through the ballot box. Meanwhile, the inequalities in academic pay in the UK, represented by what are typically perceived as the disproportionally high salaries drawn by university vice-chancellors (or presidents or principals, as they are variously titled) and their senior leadership teams are, at the time of writing, also coming under fire (see, for example, Chakrabortty 2017; Richardson 2017). And as this kind of burgeoning unrest amongst the workforces and populations of many developed countries continues to be agitated, the most prominent target in the firing line is the economic model upon which, over the last two decades or so, much of the developed world has functioned: neoliberalism; for, as Buckup (2017) argues, "[n]eoliberal economics has reached a breaking point", and "[t]he neoliberal age [has] had its day" - observations that are echoed by Zanoni et al. (2017: 575): “These 'electoral mutinies' suggest that what is under crisis is the governance system of neoliberalism itself".

For Jacques (2016), moreover, "[a] sure sign of the declining influence of neoliberalism is the rising chorus of intellectual voices raised against it". A descant to the melody created by political and economic intellectuals whose voices carry across the public space where media and electorate meet, one such chorus represents academics' articulation of the deleterious facets of life within the neoliberal university and, in some cases, their proposals for renovating the academy in a different architectural style.

\section{Out with the Neoliberal and in with the "New": Redesigning the European University}

Most academics' negativity towards the neoliberal university is expressed as critical scholarship, and as railing-against governments, and institutional senior management-that yet falls short of proposing alternative, workable scenarios. Published on the website, and therefore under the aegis, of a collaborative research project focused on Europe and the Pacific Rim, "Universities in the Knowledge Economy", the Auckland Declaration, ${ }^{1}$ for example, sets out the principles upon which its signatories believe universities in the twenty-first century should be run. But the Auckland Declaration is simply what its title implies: a declaration. It offers no tangible proposals for realising, through viable plans for restructuring higher

\footnotetext{
${ }^{1}$ http://unike.au.dk/the-auckland-declaration/.
} 
education systems and re-organising universities, the vision that its principles convey. Such limited opposition undoubtedly reflects the difficulty in conceiving of workable alternatives to the neoliberal university, for, as Kauppi (2015: 35) notes, "[n]eoliberal precepts have hijacked the future: at the moment there simply are no credible, coherently formulated political alternatives", and while Zanoni et al. (2017) highlight the need to "advance ways of organizing life other than the neoliberal one that reduces every activity to its monetary success and subjects to egomaniacs" (p. 581), they, too, fail to offer tangible proposals for how such re-organisation might be effected, and what it might result in: "[w]hat we know is changing and giving way to something new; what shape that new formation may take is not apparent yet" (p. 576, emphasis added).

The absence of a clearly defined path that will lead us to the next ideological destination, where we may lay the foundations of the post-neoliberal university, reflects the fact that its antecedent - the neoliberal university-neither evolved nor exists in a vacuum; it emerged as the product of a combination of intellectual, political and bureaucratic policymaking. Any transformation that it undergoes cannot therefore be achieved unilaterally but must span its essential tripartite constitution and reflect the complexity that this constitution ascribes to the university. Achieving this is, of course, easier said than done, and Batterbury and Byrne (2017: 30) identify a key issue that needs factoring into any realisable visions and plans for redesigning the university - it must somehow be paid for: "the problem is systemic, and financial. Running a university means managing a huge budget, paying hundreds or thousands of staff, and keeping the lights on. An ethical university, if we could somehow get back to that, will not come cheap, and this cannot be ignored". Furthermore, as Mudge (2008, p. 720) points out, "neo-liberalism reaches well beyond nationally bound politics and does not mesh neatly with right-left distinctions", so that, even at the level of government and international politics, acceptable alternatives remain elusive - and those that do present themselves as viable possibilities retain essentially market-driven dimensions.

Since it is more difficult to formulate practical plans based on envisaged scenarios that are entirely unfamiliar than it is to draw upon prior first- or second-hand experience, in any context contemplation of what a different future might look like often focuses on restoring the best of what is regretted as having been lost. Yet, despite Batterbury and Byrne's (2017) reference, cited above, to "get[ting] back to an ethical university" (emphasis added), within the academic discourse that problematizes the neoliberal academy there is evidently little appetite (see, for example, Archer 2008; Bacon 2014; Halffman and Radder 2015; Wright and Greenwood 2017a) for rekindling the past (or idealised perceptions of it). It is also important to recognise that, within the EHEA, the (most recent) past is not always or consistently imagined as a better scenario than the present "reality"; in many eastern European contexts the neoliberal ideologies that underpin higher education systems are assessed in relation to their antecedent: Soviet communism. Outlined by Hibert and Lešić-Thomas (2017) and Hvorecky et al. (2017), the ambivalence towards the neoliberal academy felt by some Eastern European-based academics, who recognise it as neither a better nor a worse alternative to the freedom-curtailing Soviet model, 
represents the kind of no-win situation that might be described in colloquial English as having leapt out of the frying pan and into the fire.

While backtracking, then - whether towards academe's "real" or imagined past, however that may be assessed - does not seem a credible basis for it, the refashioning of the twenty-first century (European) university away from its current neoliberal style is the focus of a discernible small "group" of academic activists who have taken a step beyond routine denouncement of and railing against neoliberal higher education. Members of this "group" have tried to set the ball of change rolling by initiating or contributing to a discourse that articulates what are presented as viable alternatives.

\section{A Discourse of Alternatives}

One such proposal that features within what I call the "discourse of alternatives" is the notion of a co-operative university — what Wright and Greenwoood (2017a: 1), in their editorial introduction to a journal special issue focused on "alternatives to the deteriorating state of universities", explain as: "universities run by and for the benefit of students, academics and the public". Their own article within this special issue (Wright and Greenwood 2017b) presents: "an organisational critique of the pseudo-business model currently in use [in higher education]". They propose, as a solution, re-establishing universities as trusts, through the introduction of "a model of beneficiary ownership, a matrix form of organisation and renewed relations with society" (p. 42). While Bacon (2014) proposes as "a viable and emergent management paradigm" a model of what he calls "neo-collegiality", to combat the problem of academics' lack of input into university management and governance - "university staff in the UK have little say in how their institutions are managed. ... Denial of voice represents an anachronistic approach to running universities" (pp. 1-2) - Wright and Greenwood's (2017b) proposal for involving academics and students as "collaborators and decision makers in all major institutional venues and processes" (p. 46) is more far-reaching and ambitious in scale. Drawing upon the examples of what they describe as "beneficiary-run organisations", such as the UK-based John Lewis Partnership, ${ }^{2}$ or the Mondragón University, they argue that putting the university's assets into a non-revocable trust, whereby all members become "beneficial partners, with a clear purpose to engage in satisfying work that

\footnotetext{
${ }^{2}$ The John Lewis Partnership underpins a chain of John Lewis department stores and Waitrose supermarkets, selectively located across the UK, and, with a reputation for product quality and customer service, targeting discerning middle-class consumers. The John Lewis Partnership website states that permanent staff are categorised as co-owning partners who share the business's benefits and profits: "The John Lewis Partnership is one of a growing number of businesses with an employee-owned structure and is a member of the Employee Ownership Association (EOA), the not-for-profit membership body representing the sector" (accessed 15.12.17 at: https://www. johnlewispartnership.co.uk/about.html).
} 
is socially beneficial, and an equal say in working out how the university should achieve that purpose" represents a move towards "recreating a participatory public university" (Wright and Greenwood 2017b: 47).

Mondragón University featured in a 2013 THE report that considered whether its apparent success was replicable: "can the University of Mondragon, an established higher education cooperative in the lush green mountains of the Basque Country in northern Spain, offer any answers for academies elsewhere?" (Matthews 2013). The report tells us that the university was founded in 1997 from a collection of co-ops dating back to 1943, and that its academic and administrative staff jointly own it: "[t]o become a fully fledged member, employees have to work there for at least two years, and then pay $€ 12,000 \ldots$ which buys a slice of the university's capital that can be withdrawn upon retirement ... no one at Mondragon may earn more than three times the salary of the lowest-paid worker" (Matthews 2013). Mondragón University's general assembly - the supreme body of its "highly democratic governance structure"-comprises one-third staff, one-third students and one-third outside interested parties, we are told, and its power to sack senior management team members was exercised in 2007 (Matthews 2013). Yet, while Wright and Greenwood (2017b: 47) highlight what they perceive as its key strengths-"students, faculty, administrators and staff together are the beneficiary owners and they can only pursue their interests when the consequences for all groups have been publicly discussed and agreed on. Institutional decision-making, finances and strategic planning are shared and open processes"- the THE report (Matthews 2013) uncovers several not-insignificant drawbacks of this version of a co-operative model, most of which represent revenue-related and other financial implications of its private status, including inevitable salary cuts when times are hard, and the marginalisation of arts and humanities subjects in contrast to the privileging of applied research with income-generation potential.

Meanwhile, whilst the basic idea of a co-operative university has been mooted in the UK (Matthews 2013), and a Co-operative University Working Group established, ${ }^{3}$ no firm plans for founding such a university seem yet to have emerged. Wright and Greenwood (2017b: 60) nevertheless see, as a replacement to what they label the "neo-Taylorist" (and which seems to approximate to what has come to be known as the neoliberal) university:
the creation of an operational meaning of community through the creation of legal struc- tures that engage all the participants caring for the fate of the organisation. Whether they be trusts, cooperatives or employee stock incentive systems, the underlying structure must be based on shared beneficiary ownership or engagement that strongly encourages the par- ticipants to promote the interests of their organisation and the role it plays in society.

Along broadly similar lines to the model proposed by Wright and Greenwood, Halffman and Radder's (2015) proposals for "the project of a public university aimed at the common good" (p. 175), whilst delineated within a framework whose

\footnotetext{
${ }^{3}$ https://www.co-op.ac.uk/our-work/researching-co-operatives/co-operative-university-workinggroup-cuwg/.
} 
dimensions are determined by the context of the Dutch academy, are presented as having applicability across much of the neoliberal world. Their proposed "twenty provocative first moves" (p. 176) — which they later describe (Halffman and Radder 2017:1) as "concrete measures to achieve this public university", which is "more akin to a socially engaged knowledge commons than to a corporation"-include the introduction within the university sector of, inter alia (Halffman and Radder 2015): a flatter managerial and decision-making hierarchy; a limit to time spent on administrative overheads; a policy of co-operation, rather than competition, between institutions; bans on university mergers, institutional marketing, profitable renting-out of university buildings, and student fees; and the end of "productivity" as a research assessment criterion. Yet, quite apart from the distracting polemic that runs through the narrative of resistance to academic disempowerment, proletarianisation and exploitation within which they are framed, these proposals fail to strike a chord of viability because, unlike those articulated by Wright and Greenwood (2017b), they do not draw upon a model that has been shown-albeit with limitations - to be broadly workable in at least one small corner of Europe.

Rustin's (2016: 160) "principles on which reform should be based" are directed at the development of a higher education sector that moves away from the neoliberal model by encompassing three specific "traditions or systems of value": the "industrial", the "democratic" and the "old humanist" conceptions of educational purpose and provision. "[H]ow the balance of influence between these three traditions is to be struck is fundamental", he warns, (Rustin 2016: 160), and he emphasises that "[w]e cannot be indifferent to the well-being of the economy, or to the traditions of high culture. We ... are not, after all, educational Maoists". He accordingly proposes a higher education system - paid for through a form of graduate tax-that recognises: "[p]ost-school education [as] a public as well as a private good, and ... the entitlement of all citizens, supported and funded by the democratic state". Rustin lists several "principles" that HE systems should embrace, including: stakeholder parity in institutional governance; availability to the public of higher educational institutions' (HEIs') resources, skills and knowledge output; quality assurance and inspection to underpin professional learning and development, rather than fuel competition; a shift in the epistemological basis of sectoral and systemic policy (from accountancy to educational sociology); increasing universities' role in "the making of a good society"-supported with targeted research programmes which "are now needed to provide the knowledge-base through which a new consideration can be given to the provision of tertiary education in a democratic, post-neoliberal society" (Rustin 2016: 160-167).

Aligned with the overarching premise upon which Wright and Greenwood (2017b) have developed their vision of a university "for the public good", and overlapping with several of Halffman and Radder's (2015) ideas, while yet incorporating a little more detail and specificity than do those of the Netherlands-based authors in terms of how they may be developed into a financially viable plan for university redesign, Rustin's proposals nevertheless represent rather more focus on underlying principles than on specific plans whose workability may be assessed. As attempts to convey a sense of what the redesigned, post-neoliberal university may 
look like, in common with all of the contributions to the alternative discourse outlined above, they represent preliminary impressionistic sketches rather than accurate blueprints. They can, after all, be nothing more than this, for a country's higher education system and the model of university that it will feature cannot be designed by intellectual analysis in isolation, detached from whatever political, economic and bureaucratic models evolve, emerge, or are strategically implemented. Yet, in terms of redirecting policy and practice, small steps can surely be taken that, cumulatively, may begin to restructure the landscape of higher education in Europe.

\section{Reshaping the EHEA: Eroding the European Neoliberal Academy by Degrees}

The neoliberal university is one whose policies and practices reflect the influence of market forces - most typically through performativity cultures and the commodification of resources (including staff), and the more specific ways in which these manifest themselves. Redesign or evolution into a different-non- (or post-) neoliberal-university involves relinquishing such "trappings" of neoliberalism. And since there are, of course, degrees of neoliberalism, dismantling it progressively and gradually is a more likely scenario than is sudden widespread strategic reform (though the two approaches are not mutually exclusive and may be used in conjunction); so we may conceive of transitions that involve, for example, diluted or reduced neoliberalism, as preludes to eventual total "abstinence" from it—or that retain residual neoliberal features. Such incremental reshaping of the EHEA is likely to be achieved through a snowballing effect, whereby this or that initiative undertaken in a single European region or country —or even in a single universityincreases in size and scope as it rolls along and gathers momentum, through being adopted or adapted by others who see some merit in it by recognising it as a "better way".

\section{Recognition of a "Better Way": The Micro-level Dimension of Reshaping a Post-neoliberal EHEA}

This notion of recognising something as a "better way" is a key feature of the process of effective change; I have highlighted its fundamental importance (e.g. Evans 2014, 2018) to several aspects of leadership and the development of education workforces in the compulsory and the higher education sectors-including measures directed towards enhancing professionalism.

Within the sociology of professions, professionalism is now accepted as a contested concept, and the academic discourse has moved on (see, for example, Evetts 2003, 2013; Gewirtz et al. 2009; Noordegraaf 2007) from the focus (that was 
prevalent in the twentieth century) on trait-based elitist notions of which occupational groups merit professional status, and on what bases. Consistent with my own conceptualisations and definitions of professionalism and professional development (presented, for example, in Evans 2013, 2014, 2018), I argue (Evans 2011) that, whether they be at the meso (e.g. institutional) or macro (e.g. sectoral or national) level, attempts at renovating or changing a workforce's professionalism constitute intended large-scale professional development. Moreover, for such professional development to be effective in shaping "new" professionalisms, the workforcesthe professionals - targeted must "buy into" the refashioned professionalism that is promoted, by recognising it as, for them, currently a "better way": a "better" professionalism, on balance, than the one it is intended to replace.

These issues are relevant to the discussion in this chapter because this facet of work psychology — people's tendency to embrace what they judge to improve, and to resent what they consider to (potentially) impoverish, their work-related lives-is crucial to understanding not only academics' (and, in many respects, students') attitudes towards the neoliberal academy, but also their likely attitudes towards whatever may replace it. Essentially, then, just as the neoliberal university is so widely perceived as having created work (or study) situations that I describe as "compromising" (Evans 1998, 2001, 2018), since they distance people from their "ideals" by requiring them to compromise on their values and ideologies, the post-neoliberal university that eventually replaces it must, if it is to be assessed as representing a "better way", contribute towards creating for people more "uncompromising" work situations (Evans 2001, 2018) that better match their values and ideologies. This may be achieved by facilitating and fostering "new" academic professionalisms that are perceived as more acceptable - and hence as representing a "better way" - than those that have evolved to reflect neoliberal ideologies.

It is surprising that, whilst they are evident within the initial anti-neoliberal academic discourse that rails against the system, such work psychology-related issues scarcely feature within the associated "discourse of alternatives", for they are fundamental to consideration of what an acceptable and effective post-neoliberal European academy might look like; indeed, they should inform the point of departure of such consideration. Having highlighted the difficulties of conceiving of a viable "top-down", "big picture" vision of a political- or economic-generated alternative to the neoliberal model of organising and running higher education, I argue that we should consider reshaping the EHEA from a micro-level starting point: the constituent components and dimensions of European academics' professionalism(s).

\section{The Building Blocks of a Post-neoliberal EHEA: European Academics' Professionalism(s)}

It is evident from a plethora of studies (e.g. Archer 2008; Clegg 2008; Erkkilä and Piironen 2015; Kauppi 2015; Ylijoki and Ursin 2015) that the European neoliberal university, as I observe elsewhere (Evans 2018), has not got the best out of its 
academics; for the most part, it seems to have increased precarity, fostered instability, unsettled identities, and consequently eroded morale. Scaled up, this evidence leads us to reason that the neoliberal EHEA has not got the best out of its academics. Yet turning the page on such tense academic workplace conditions and relations by starting a new chapter in the development of the European academy - a chapter that both precipitates and is precipitated by, the decline of higher education's neoliberal era - presents the opportunity to redraft the EHEA's psychological contract with its academics by reshaping the professionalism "demanded" of them.

More precisely, such professionalism-(re)shaping would in fact represent initial drafting, rather than redrafting, since neither the Bologna Process nor the EHEA explicitly delineates the shape or nature of European academic professionalism that are either "prescribed" or "demanded (or requested)". ${ }^{4}$ Certainly, since they are promoted and facilitated by the Bologna process, receptivity to international mobility, collaboration and co-operation are implicitly identified as features of what we may think of as EHEA-approved academic professionalism, but other than such implications, what the European academic (including at the pre-employment, early career stage) may reasonably be expected to "look like" (or aspire to look like) remains largely unarticulated - a lacuna that, with a specific focus on researcher development in Europe, I address elsewhere (Evans 2015).

Shown in diagram form in Fig. 1, my conceptualisation of it $^{5}$ presents professionalism as a qualitatively neutral, rather than a merit-laden, concept that denotes people's "mode of being" in relation to their work-simply, how they go about it and what influences them to do so. I conceive of professionalism as trifurcated into three components - behavioural, intellectual and attitudinal - which, collectively, are constituted of eleven sub-components, or dimensions, relating to people's: perceptions, values, motivation (along with morale and job satisfaction), knowledge and understanding, skills and competences, rationality and analyticism, the bases of their knowledge and knowledge structures, and the processes and procedures that they apply to their work, as well as their output and productivity: how much they "do" or produce at work.

In conveying its expectations of them, the neoliberal academy-through the agency of universities as employing institutions, and reinforced and perpetuated by institutional rankings-determined competitive cultural hegemony (Erkkilä and Piironen 2015) - has imposed on academics a "demanded" professionalism whose shape is reflected in how particular neoliberal-derived interpretations of the nature and purpose of higher education are translated into each of the eleven dimensions shown in Fig. 1.

Moreover, through its acceptance of the institutional competitiveness that is a dominant feature of its landscape, the EHEA may even be considered complicit in

\footnotetext{
${ }^{4}$ See Evans (2013), (2018) for a full explanation of what I variously label four "reified states" or "perspectival versions" of professionalism: "demanded (or requested)", "prescribed", "deduced (or assumed)" and "enacted" professionalism.

${ }^{5}$ This conceptualisation is explained in detail elsewhere (e.g. Evans 2014, 2018, and, adapted to relate to researcher professionalism, in Evans 2015).
} 


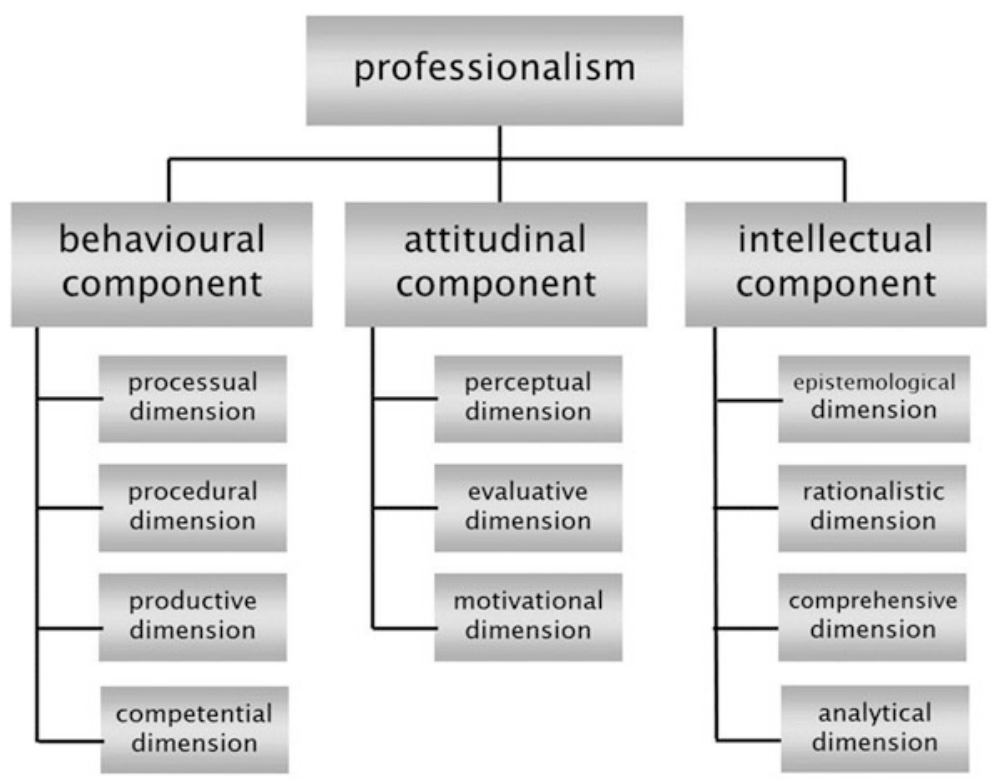

Fig. 1 The componential structure of professionalism

"demanding" of academics such a neoliberal-shaped professionalism. Turning the page on such complicity, then, by way of revisiting the Bologna Process, a new priority for the future of the EHEA beyond 2020, to mark its tenth anniversary, could be added to the list of priorities identified in the 2015 Yerevan Communiqué: the promotion of an explicit new, post-neoliberal, European academic professionalism.

\section{The "Shape" of an EHEA-Approved Post-neoliberal Academic Professionalism}

What would such a new European academic professionalism look like? To address this question it may be helpful to consider the embodiment of the professionalism in the person of the notional post-neoliberal European academic. Applying as a loose analytical and descriptive framework my conceptual model shown in Fig. 1, we may envisage such an academic as someone who, for example, rather than be influenced by consideration of their potential cost-effectiveness or profitability in deciding what activity processes to engage in and what procedures to follow, feels free to develop and nurture relationships or to respond to approaches and inquiries (from colleagues, students, and members of the public) for their own sake; to be more altruistically-focused than was generally possible within the neoliberal academy. She feels freer to pursue the kinds of "slow scholarship"-akin to what Sullivan (2014: 10) refers to as "measured thought and unhurried instruction- 
'life of the mind' concept" - that some detractors of the neoliberal academy lament as having been eroded (e.g. Mountz et al. 2015). Depending on her discipline, the post-neoliberal European academic may not need to be preoccupied with securing increasingly scarce research funds, because she knows that she has, or is being given the time and space to develop, other skills from which her university will benefit - such as curriculum development or teaching skills that will enhance its educational provision, or analytical and academic writing skills that will allow the institution to bask in the reflected glory from her internationally recognised scholarship that demonstrates her capacity for generating ground-breaking theoretical perspectives or policy recommendations that have the potential to contribute to societal growth. The post-neoliberal European academic is comfortable with the principles and ideologies upon which are based her university's strategic development agenda, because these are no longer focused on consideration of the need for everything to pay its way; rather, they are compatible with her own values that reflect a concern for social justice, equality of opportunity, and a perception of higher education as a vehicle for societal enhancement through a focus on public good, rather than profitability (in its widest sense). Her self-perception-her identity - is as an academic who is making a contribution to achieving such ideals, through her work in a university that shares her values, so, for the most part, she is able to buy into her university's mission. This means, too, that for much of the time she is motivated and enjoys high morale and job satisfaction.

But how might the EHEA, as it moves towards the next era of its development, facilitate such evolution?

\section{EHEA-Facilitated Transition Towards a Post-neoliberal European Academy}

A product of the Bologna Process, the EHEA is an enigmatic combination of real, physical entities-Europe's higher education institutions and the organisations (such as national ministries of higher education) that determine the parameters of their governance - and ideas, ideologies and principles that shape visions of Europe as a fluid, joined-up space. This is a space within which students and academics are ideally conceived of as moving about with few constraints, accessing and contributing to the provision of shared resources (including knowledge), for the purpose of augmenting Europe's growth as a cohesive society and its capacity and position and standing in the world as an intellectual superpower or knowledge-generator and -broker, in partnership with the European research area (ERA), through the achievements and for the benefit of these transient (in either a virtual or physical sense) Europe-based students and academics. Any-the onlyform of agency that the EHEA may exercise as an agentic unity must be through agreements, commitments and declarations made in recognised official fora, such as ministerial conferences, and "ratified" in the reports and communiqués that emerge from these. Yet such "ratification" may turn out to be not worth the paper it is written on if implementation is patchy; indeed, Tibor Navracsics (European 
Commissioner responsible for education, culture and sport, 2014-2019) observed in the 2015 Bologna Process Implementation Report (European Commission/EACEA/ Eurydice 2015: 3) that "[a]lthough countries are moving in the same direction, they do so at widely varying pace. As a result, the foundations of the European Higher Education Area are not yet fully stable". What hope, then, is there that this somewhat nebulous - and in some respects, amorphous - entity that is the EHEA may take the initiative to refashion itself in a post-neoliberal style, through promoting the kind of renovated academic professionalism whose general shape I sketch out above?

There is undoubtedly the facility to place a focus on the "European" academic and her or his professionalism (as I interpret the term) on the EHEA development agenda. Yet it is both interesting and disappointing to note that, hitherto, despite passing reference in the European Commission's modernisation agenda (European Commission 2011, cited in European Commission/EACEA/Eurydice 2017) that implicitly recognises "the importance of staff" (European Commission/EACEA/ Eurydice 2017: 3), agendas of ministerial conferences, and therefore of the reports on the progress of the EHEA's development and of the implementation of the Bologna Process, have so far failed to incorporate such a micro-level focus on the people - the individuals - who are at the front line of delivering higher education in Europe. The evident lack of recognition both that it is they who are the key instruments in ensuring the quality of European higher education, and of the importance of work psychology in elucidating how to get the best out of them in such roles, is unfathomable. The contents page of the 2015 Bologna Process Implementation Report (European Commission/EACEA/Eurydice 2015) lists as topics and issues covered: the context of the EHEA; degrees and qualifications; quality assurance; the social dimension of higher education; lifelong learning; effective outcomes and employability; and internationalisation and mobility. A glaring omission is the higher education workforce and the university/higher education institution as a workplace; this topic is not covered-it is not even mentioned in passing - within any of the chapters to which it may reasonably be considered to relate, such as the one on quality assurance. Yet since it is an issue that, to varying degrees, underpins and/or impacts upon all of these listed topicsindeed, Navracsics notes that "Policy makers, academic staff and students must work together, within countries and across borders, to learn from each other and to identify and achieve measurable objectives" (European Commission/EACEA/ Eurydice 2015: 3, emphases added) — it surely merits its own place on the ministerial discourse agenda, and its own chapter in reports and documentation of progress in reforming and strengthening the EHEA.

There is, however, a glimmer of hope that the European academic workforce and its welfare and consequent capacity to deliver high quality higher education is finally being recognised as a significant issue. A 2017 Eurydice brief identifies the historic neglect of this issue as the impetus for the project whose findings it presents: 
While higher education has been subject to increasing demands amidst fast-moving societal transformation, little attention has been paid to the staff at the centre of the picture. Change in the higher education environment means that there are inevitably changes to the expectations, work roles, status and professional conditions of academic staff. The lack of Europe-wide investigation into the situation for academic staff gave rise to this project that set out to explore the academic profession in different countries, cultures and institutions. (European Commission/EACEA/Eurydice 2017: 3, emphases added)

As occurs with all such reports published under the aegis of the European Commission, however, the 2017 Eurydice brief is disappointingly limited to the presentation of quantitative data, mainly in the form of descriptive statistics, supplemented by very brief commentary; superficiality of focus dilutes elucidatory capacity, so that all we may glean are general overviews. Regrettably, the kinds of micro-level issues that I highlight above as important do not feature.

Consistent with the criticism I have levelled at the Bologna discourse on doctoral education (Evans 2015), I repeat that guiding principles, as the typical products of this discourse, are too general and wishy-washy to have a meaningful and transformative impact on the quality of European higher education provision and output. Greater specificity needs to be incorporated into agreed processes and procedures, including the provision of yardsticks that clearly delineate and illustrate standards (which could vary to reflect, and apply differentially to, different national or regional circumstances, stages of development, and cultures) against which achievements and progress at the micro and meso levels may be evaluated, that will take us - the European academic community - forward. In relation to reshaping European academic professionalism for the EHEA's transition into a post-neoliberal era, such specificity could take the form of agreed policies and practices that European higher education institutions (HEIs), through their ministries, would sign up to, in much the same way that they signed up to the degree structures and mobility-facilitating mechanisms that are so integral to the Bologna Process. These structures and mechanisms have evidently been adopted by a great many European HEIs, despite the profound changes to academic life they are perceived to have wrought in some countries (see, for example, Evans and Cosnefroy 2013; Rege Colet 2015 for accounts of the perceived impact of the Bologna Process on academics and academic working life in France and in Switzerland). There is therefore no reason to assume an unwillingness to co-operate in introducing incremental changes to institutional policy and practices that would be directed towards re-motivating the academic workforce to deliver the European-the EHEA'svision, through fostering a "new" post-neoliberal academic professionalism.

At the heart of the neoliberal academy, sustaining and perpetuating it, are global university ranking systems. These spawn inter-institutional competition and undermine co-operation, since league table positions tend to be equated with income-generation capacity. Yet, as Lim (2018: 428) observes, "higher education leaders have the capacity to reflect, resist, and, importantly, shape the metrics by which they accept to be "judged"'. So, too, does the EHEA, for, as Kauppi (2015: 44) suggests: 
If going back is not a realistic option, linguistic counter-strategies might involve using quotation marks when using key concepts such as excellence, thereby indicating the distance between old and new content or inventing new concepts to construct an alternative reality. However, purely linguistic strategies are effective only if linked with transformations in social practices, in what academics do in their everyday activities.

To both support and precipitate academe's transition towards its post-neoliberal era, the EHEA could feasibly identify and agree on the kinds of values and principles for which it wishes to be recognised, effectively initiating and promoting the kinds of "alternative" criteria for judging institutional prestige, reputation and success that support and sustain a "new" European academic professionalism.

If the EHEA does not take the initiative in introducing such changes-including by adding to its discourse agenda the topic of the academic workforce and academic working life - there is a very real likelihood that some of its member nations, or, within these, individual HEIs, will unilaterally set the ball of change rolling across Europe. Indeed, there are signs that such a snowballing-type transition is about to be kick-started-in Scandinavia.

\section{The Dawn of a Scandinavian-Led "New" European Academic Professionalism?}

The nature or speed of any post-neoliberal transition that may occur within the EHEA will inevitably depend upon various regional, national and geo-cultural and political contextual factors. Eastern European countries, for example, having only relatively recently "embraced" some aspects of neoliberalism, may perhaps be slower and more reluctant to change than may their western European neighbours. Many European countries' higher education systems are centralised, so that, to varying degrees, how their universities are run may be determined at government level, and is sometimes enshrined in law. Within such centralised contexts, the form and nature of the university, and the shape of its academics' professionalism, cannot simply emerge incrementally through a snowballing process; they must be planned, agreed and, effectively, "decreed". In decentralised higher education systems, in contrast, where - as in the UK - universities enjoy considerable autonomy, those of their features that denote neoliberalism may, if there is a will, be eroded unilaterally.

Evidently directed both at individual HEIs and at the UK's wider higher education "system", Peter Scott's rallying cry, published in the Guardian newspaper, represents a wake-up call that urges a policy re-think if universities are to avoid:

ending up on the wrong side of history. They will be seen as accomplices in failing neoliberal markets, against which their students are in revolt, and spurious "modernisation", which alienates many of their staff. They need to get back on the right side of historyquickly. (Scott 2017)

Elsewhere in this Guardian piece, Scott makes a valid point that I touch upon above: that old (neoliberal) habits die hard, so it is difficult to conceive-let alone delineate the features - of a university that is run and organised in any other way, and on any other basis. Yet, even without a comprehensive vision of what the 
refashioned university in its entirety will look like and how it will be financed, changes to or the relinquishment of specific neoliberal policies or practices have the capacity to erode the hegemony of neoliberal ideology. The replacement of performativity cultures and audit mechanisms, for example, with what Myklebust (2017) — attributing it to Jouke de Vries, professor of governance and public policy at the University of Groningen in the Netherlands - describes as "a more holistic governance approach based on 'confidence governance', or the 'public value' approach in public administration ... where management objectives are reached through trust and legitimacy rather than through measurements and control" would represent a step towards university redesign that incorporates and is based upon consideration of how to motivate and get the best out of the academic workforce.

Such change is evidently on the cards for Swedish universities, Myklebust (2017) tells us - quoting Swedish prime minister Stefan Löfven's declaration that "[t]he time for New Public Management now is ended". Myklebust reports on a mandate from the Minister for Public Administration in the Ministry of Finance, Ardalan Shekarabi, to the Swedish Agency for Public Management, to work out a new proposal for public governance and leadership systems in public administration. Endorsed by the prime minister, "[t]he mandate included a reduction of reporting and documentation, better inclusion of staff members' competence and experience, and development of governance to become more 'holistic and effective', based on 'confidence governance"' (Myklebust 2017). The vision of higher education implied by such ideas and proposals is very similar to that articulated by Scandinavian academics Erkkilä and Piironen (2015), summed up as follows:

\footnotetext{
Understanding academic work as collaboration involving a global research community would allow one to perceive academic work differently. Seen from this perspective, scientific progress would be a collective effort that is not the sum of the actors engaging in it but rather a social process that cannot be reduced to individuals. For this system to perform at its best, we need a reappraisal of professional values and academic identities. (p. 60, emphasis added)
}

It may be through such relatively small steps, rather than through programmes of sweeping reform, that the European university ends up being refashioned. It may even be through the brave actions of a single university, whose senior leaders and managers decide to go out on a limb and make a name for their institution as a pioneering reformist institution - the first one in their country (let's say, the UK) to wander off the neoliberal highway and step out onto the post-neoliberal path by, for example, reducing or abolishing tuition fees, or telling academics (at least, in some disciplines) that they should no longer feel obliged to relentlessly chase research funding that is about as accessible as the pot of gold at the end of the rainbow, or by relinquishing the goal to achieve, within the next five years, ranking as one of the world's top fifty or twenty-five universities. It may be, as we may infer from Myklebust's (2017) report, that Swedish universities will realign themselves with what Ylijoki and Ursin (2015: 187) refer to as "the Nordic welfare state model that perceived higher education as a public good" and will lead the rest of the EHEA into the next, post-neoliberal, phase of its development. Or it may be that in 
one or other European country a new economic model is adopted by a newly elected government - such as a Corbynist Labour government in the UK - and the accompanying redesign of its higher education system paves the way for re-shaping the EHEA by degrees.

\section{Concluding Thoughts}

"The neoliberal age [has] had its day", insists Buckup (2017) — "It is time to define what comes next". Jacques (2016), too, argues that "the neoliberals and monetarists are in retreat", but adds: "[i]n the UK, the media and political worlds are well behind the curve. Few recognise that we are at the end of an era". It seems, too-as Scott (2017), cited above, notes - that those who call the shots in universities are burying their heads in the sand. As I argue elsewhere (Evans 2018: 246), "the marketised university is not about to rebrand itself in a hurry" - not only because universities are in denial, but also because they have no idea what that new brand will look like, how they may appropriate it, and, above all, what it will cost and how they may hope to meet that cost. In this respect they are evidently not alone, for, as Westwood (2017) points out, despite its 2016 general election manifesto to abolish student tuition fees in England, post-election, the UK's Labour party remains vague on the detail of how this may be achieved.

Through its scholarly discourse and its politicised engagement with institutional and sectoral leaders and managers, Europe's academic community has, since around the turn of the millennium, become increasingly vocal in expressing its concerns about its workplace environment: the neoliberal university that has shaped the EHEA. For the most part, it seems, these concerns have fallen on deaf ears. But the political unpredictability and upsets that began to feature in the latter half of the 2010s have shown that those who used to call the shots have become less audible: less certain of their ground; less confident of their authority. They have had to sit up and take notice of the popular voice. They have had to listen, and to demonstrate that they have heard-as has the UK government, in launching in February 2018 a year-long review of post-18 education and funding that includes reviewing higher education tuition fees. ${ }^{6}$ European higher education now "stands at a crossroads", warn Erkkilä and Piironen (2015: 55). The time is surely ripe, then, for opening our ears to the death knells of Europe's neoliberal university, and turning our attention to how the EHEA may be reshaped after its inevitable demise.

\footnotetext{
${ }^{6}$ For the review's terms of reference, see: https://www.gov.uk/government/uploads/system/ uploads/attachment_data/file/682348/Post_18_review_-_ToR.pdf, accessed on 28.02.18.
} 


\section{References}

Archer, L. (2008). The new neoliberal subjects? Young/er academics' constructions of professional identity. Journal of Education Policy, 23(3), 256-285.

Bacon, E. (2014). Neo-collegiality: Restoring academic engagement in the managerial university. London: The Leadership Foundation for Higher Education.

Batterbury, S., \& Byrne, J. (2017). Australia: Reclaiming the Public University? In W. Halffman \& $\mathrm{H}$. Radder (Eds.), International responses to the academic manifesto: Reports from 14 countries, social epistemology review and reply collective, special report (pp. 23-32).

Bock, P. (2017). The new French revolution: How En Marche! Disrupted politics. The New Statesman, 23rd June. Retrieved 6 Sep 2017, from http://www.newstatesman.com/culture/ 2017/06/new-french-revolution-how-en-marche-disrupted-politics.

Buckup, S. (2017). The end of neoliberalism? World economic forum. Retrieved 7 Sep 2017 from https://www.weforum.org/agenda/2017/07/this-is-what-the-future-of-economic-liberalismlooks-like-its-time-to-rethink-it/.

Chakrabortty, A. (2017). The fat cats have got their claws into our universities, and will eat them up. The Guardian, 28th November. Retrieved 15 Dec 2017, from: https://www.theguardian. com/commentisfree/2017/nov/28/fat-cats-britains-universities-vice-chancellors-salaries-pay.

Clegg, S. (2008). Academic identities under threat? British Educational Research Journal, 34(3), 329-345.

Erkkilä, T., \& Piironen, O. (2015). Autonomisation and individualisation: Ideational shifts in European higher education. In L. Evans \& J. Nixon (Eds.), Academic identities in higher education: The changing European landscape (pp. 47-62). London: Bloomsbury.

European Commission/EACEA/Eurydice. (2015). The European higher education area in 2015: Bologna process implementation report. Luxembourg: Publications Office of the European Union.

European Commission/EACEA/Eurydice. (2017). Eurydice brief: Modernisation of higher education in Europe: Academic staff-2017. Luxembourg, Publications Office of the European Union.

Evans, L. (1998). Teacher morale, job satisfaction and motivation. London: Paul Chapman.

Evans, L. (2001). Delving deeper into morale, job satisfaction and motivation among education professionals: Re-examining the leadership dimension. Educational Management and Administration, 29(3), 291-306.

Evans, L. (2011). The "shape" of teacher professionalism in England: Professional standards, performance management, professional development, and the changes proposed in the 2010 white paper. British Educational Research Journal, 37(5), 851-870.

Evans, L. (2013). The professional status of educational research: Professionalism and developmentalism in 21st century working life. British Journal of Educational Studies, 61 (4), 471-490.

Evans, L. (2014). Leadership for professional development and learning: Enhancing our understanding of how teachers develop. Cambridge Journal of Education, 44(2), 179-198.

Evans, L. (2015). Enhancing the quality of research in Europe: Theoretical perspectives on and guiding principles for researcher development. In A. Curaj, L. Matei, R. Pricopie, J. Salmi, \& P. Scott (Eds.), The European higher education area: Between critical reflections and future policies: Part II (pp. 583-602). Dordrecht: Springer.

Evans, L. (2018). Professors as academic leaders: Expectations, enacted professionalism and evolving roles. London: Bloomsbury.

Evans, L., \& Cosnefroy, L. (2013). The dawn of a new academic professionalism in the French academy? Academics facing the challenges of imposed reform. Studies in Higher Education, 38(8), 1201-1221.

Evetts, J. (2003). The sociological analysis of professionalism: Occupational change in the modern world. International Sociology, 18(2), 395-415.

Evetts, J. (2013). Professionalism: Value and ideology. Current Sociology, 61(5-6), 778-796. 
Gewirtz, S., Mahony, P., Hextall, I., \& Cribb, A. (2009). Policy, professionalism and practice: Understanding and enhancing teachers' work. In S. Gewirtz, P. Mahony, I. Hextall, \& A. Cribb (Eds.), Changing teacher professionalism (pp. 3-16). London: Routledge.

Halffman, W., \& Radder, H. (2015). The academic manifesto: From an occupied to a Public University. Minerva, 53(2), 165-187.

Halffman, W., \& Radder, H. (Eds.). (2017). International responses to the academic manifesto: Reports from 14 countries. Social epistemology review and reply collective, special report (pp. 1-76).

Hibert, M., \& Lešić-Thomas, A. (2017). On wolves, sheep and shepherds: A Bosnian comedy of errors. In W. Halffman, \& H. Radder (Eds.), International responses to the academic manifesto: Reports from 14 countries, social epistemology review and reply collective, special report (pp. 33-36).

Hvorecky, J., Višňovsky, E., \& Porubjak, E. (2017). Striving for academic authenticity: A Slovak position in the context of the academic manifesto. In W. Halffman, \& H. Radder (Eds.), International responses to the academic manifesto: Reports from 14 countries, social epistemology review and reply collective, special report (pp. 41-44).

Jacques, M. (2016). The death of neoliberalism and the crisis in western politics. The Guardian, 21st August. Retrieved 7 Sep 2017, from https://www.theguardian.com/commentisfree/2016/ aug/21/death-of-neoliberalism-crisis-in-western-politics.

Kauppi, N. (2015). The academic condition: Unstable structures, ambivalent narratives, dislocated identities. In L. Evans \& J. Nixon (Eds.), Academic identities in higher education: The changing European landscape (pp. 31-46). London: Bloomsbury.

Lim, M. A. (2018). The building of weak expertise: The work of global university rankers. Higher Education, 75(3), 415-430.

Mason, P. (2015). Postcapitalism: A guide to our future. London: Allen Lane.

Matthews, D. (2013). Inside a cooperative university. Times Higher Education, August 29th. Retrieved 15 Sep 2017, from https:/www.timeshighereducation.com/features/inside-acooperative-university/2006776.article.

Mountz, A., Bonds, A., Mansfield, B., Loyd, J., Hyndman, J., \& Walton-Roberts, M., et al. (2015). For slow scholarship: A feminist politics of resistance through collective action in the neoliberal university. ACME: An International Journal for Critical Geographies, 14(4), 1235-1259. Retrieved 20 Oct 2017, from https://www.acme-journal.org/index.php/acme/ article/view/1058.

Mudge, S. L. (2008). What is neo-liberalism? Socio-Economic Review, 6(4), 703-731.

Myklebust, J. P. (2017). In search of a new form of University Governance. University World News (450). Retrieved 10 Mar from http://www.universityworldnews.com/article.php?story= 2017030918094136.

Noordegraaf, M. (2007). From "pure" to "hybrid" professionalism: Present-day professionalism in ambiguous public domains. Administration and Society, 39(6), 761-785.

Rege Colet, N. (2015). Changing policy, changing identities: Being and leading academics in the developing Swiss higher education sector. In L. Evans \& J. Nixon (Eds.), Academic identities in higher education: The changing European landscape (pp. 83-98). London: Bloomsbury.

Richardson, H. (2017). University heads asked to justify pay over $£ 150,000$. BBC News Online, 7 September. Retrieved 15 Dec 2017, from: http://www.bbc.co.uk/news/education-41176337.

Rustin, M. (2016). The neoliberal university and its alternatives. Soundings, 63, 147-171.

Scott, P. (2017). The end of tuition fees is on the horizon-universities must get ready. The Guardian, 4th July. Retrieved 4 July 2017, from https://www.theguardian.com/education/2017/ jul/04/end-tuition-fees-universities-get-ready.

Sullivan, T. A. (2014). Greedy institutions, overwork and work-life balance. Sociological Inquiry, 84(1), 1-15.

Westwood, A. (2017). Labour 2017: Fees pledge keeps party in campaign mode, but detail is lacking. The Times Higher Education, 26 Sep. 
Wright, S., \& Greenwood, D. J. (2017a). Introduction. Recreating universities for the public good: Pathways to a better world. Learning and Teaching: The International Journal of Higher Education in the Social Sciences, 10(1), 1-4.

Wright, S., \& Greenwood, D. J. (2017b). Universities run for, by, and with the faculty, students and staff: Alternatives to the neoliberal destruction of higher education. Learning and Teaching: The International Journal of Higher Education in the Social Sciences, 10(1), 42-65.

Ylijoki, O.-H., \& Ursin, J. (2015). High-flyers and underdogs: The polarisation of Finnish academic identities. In L. Evans \& J. Nixon (Eds.), Academic identities in higher education: The changing European landscape (pp. 187-202). London: Bloomsbury.

Zanoni, P., Contu, A., Healy, S., \& Mir, R. (2017). Post-capitalistic politics in the making: The imaginary and praxis of alternative economies. Organization, 24(5), 575-588.

Open Access This chapter is licensed under the terms of the Creative Commons Attribution 4.0 International License (http://creativecommons.org/licenses/by/4.0/), which permits use, sharing, adaptation, distribution and reproduction in any medium or format, as long as you give appropriate credit to the original author(s) and the source, provide a link to the Creative Commons license and indicate if changes were made.

The images or other third party material in this chapter are included in the chapter's Creative Commons license, unless indicated otherwise in a credit line to the material. If material is not included in the chapter's Creative Commons license and your intended use is not permitted by statutory regulation or exceeds the permitted use, you will need to obtain permission directly from the copyright holder.

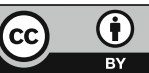

